\title{
ВМІСТ САПОНІНІВ У КОРЕНЕВИЩАХ 3 КОРЕНЯМИ ТА ЛИСТКАХ ПЕРВОЦВІТУ ВЕСНЯНОГО
}

Вступ. Первоцвіт, або примула (Primula L.), - рід рослин родини первоцвіті (Primulaceae), який нараховує близько 500 видів, поширених по всій земній кулі. У країнах СНД росте 67 видів (за даними деяких авторів 80) роду, в Україні - 9; найпоширеніший - первоцвіт весняний. Первоцвіт весняний (Primula veris L.) лікарська, вітамінна, харчова, медоносна, фрарбувальна, декоративна рослина. Незважаючи на широке використання первоцвіту весняного в медичній практиці, хімічний склад його вивчено недостатньо. У доступних джерелах наукової літератури відсутні дані про дослідження вмісту сапонінів у листках $i$ підземних органах первоцвіту весняного фрлори України.

Мета дослідження - визначити вміст сапонінів у листках і кореневищах з коренями первоцвіту весняного

Методи дослідження. На наявність сапонінів досліджували водну і спиртово-водну витяжку листків та кореневищ з коренями первоцвіту весняного. Водну витяжку первоцвіту весняного використовували для проведення проби на піноутворення і деяких осадових реакцій. Також визначали хімічну природу сапонінів. Кількісний вміст сапонінів визначали спектрофотометричним методом на спектрофротометрі Lambda 25 UV при довжині хвиль 381 нм. Перерахунок вели на есцин.

Результати й обговорення. Поява стійкої піни та позитивні реакції з 10 \% розчином основного плюмбуму ацетату й 1 \% спиртовим розчином холестерину свідчили про наявність сапонінів у кореневищах з коренями і листках досліджуваної рослини. При визначенні хімічної природи сапонінів встановлено, що листки та кореневища з коренями первоцвіту весняного містять сапоніни тритерпенового ряду. Результати досліджень показали, що листки первоцвіту весняного містять $(1,27 \pm 0,02) \%$ сапонінів у перерахунку на есцин, кореневища з коренями - $(3,69 \pm 0,02) \%$.

Висновки. Експериментально доведено, що листки і кореневища з коренями первоцвіту весняного містять сапоніни тритерпенового ряду. Вперше визначено кількісний вміст сапонінів у листках і підземних органах первоцвіту весняного, заготовлених на території Тернопільської області. Вміст сапонінів у листках становив 1,27 \%, у кореневищах з коренями - 3,69 \% у перерахунку на есцин.

КЛЮЧОВІ СЛОВА: первоцвіт весняний; сапоніни; листки; кореневища з коренями.

ВСТУП. Первоцвіт, або примула (Primula L.), - рід рослин родини первоцвіті (Primulaceae), який у світовій фрлорі представлений багато- й однорічними травами. Відомо близько 500 видів роду, поширених по всій земній кулі, але переважно в помірному поясі та альпійському поясі гір. У країнах СНД росте 67 видів (за даними деяких авторів [1] - 80) роду, в Україні - 9; найпоширеніший - первоцвіт весняний [2, 3].

Первоцвіт весняний (Primula veris L.; Primula officinalis Hill.) - багаторічна трав'яниста рослина з косим кореневищем, розеткою прикореневих листків і квітконосними стрілками. Листки яйцеподібні або довгасто-місяцеподібні, тупі, зморшкуваті, з хвилястим зарубчасто-виїмчастим

(․ С. М. Марчишин, Л. Г. Шостак, С. С. Наконечна, Т. Я. Ярошенко, 2017. краєм, опушені або майже голі з вузькокрилатим черешком. Суцвіття зонтикоподібне, однобічне, з обгорткою з лінійних листочків. Квітки правильні, зрослопелюсткові, на квітконіжках, яскраво-жовтого кольору.

Первоцвіт весняний - лікарська, вітамінна, харчова, медоносна, фрарбувальна, декоративна рослина.

У народній медицині відвар, настойку і сироп кореневищ 3 коренями первоцвіту весняного використовують як відхаркувальний засіб при лікуванні туберкульозу, бронхіту, астми, пневмонії, коклюшу; як седативний, спазмолітичний, легкий проносний засіб, як болезаспокійливий засіб при судомах і паралічах, як діуретичний засіб при всіх хворобах сечових шляхів та нирок; настій - при закрепах, безсонні, загальній сла- 
бості, поганому апетиті, кашлі, запамороченні [4]. Листки в народній медицині застосовують для лікування гіпо- й авітамінозів. Настій листків рекомендують при подагрі, хворобах нирок і сечового міхура.

Незважаючи на широке використання даної рослини в медичній практиці, хімічний склад їі вивчено недостатньо. У доступних джерелах наукової літератури відсутні дані про дослідження вмісту сапонінів у листках і підземних органах первоцвіту весняного фрлори України.

Сапоніни - поліциклічні природні сполуки, в основному рослинного походження, які використовують у легкій, харчовій, косметичній і фрармацевтичній промисловості як натуральні поверхнево-активні речовини. Вони мають різноманітну фармакологічну активність, більшість 3 них підсилює секреторну діяльність залоз, сприяє всмоктуванню інших речовин, зумовлює відхаркувальну активність, деякі з них мають сечогінну, антиалергічну, противірусну дію, регулюють водно-сольовий обмін. Сапоніни також тонізують діяльність центральної нервової системи, проявляють гіпотензивний, протизапальний, антимікробний, протиалергічний і кортикостероїдний есректи [5]. У джерелах наукової літератури є також інфрормація про адаптогенну, антисклеротичну і гіпоглікемічну активність сапонінів [6, 7].

Мета дослідження - визначити вміст сапонінів у листках і кореневищах з коренями первоцвіту весняного.

МЕТОДИ ДОСЛІДЖЕННЯ. ДЛЯ поглибленого фрармакогностичного дослідження було обрано листки та кореневища з коренями первоцвіту весняного, які заготовляли на території Тернопільського району (околиці с. Глибочок) Тернопільської області у 2012-2015 рр. Листки заготовляли під час цвітіння рослини (кінець квітня - початок травня), кореневища 3 коренями восени після відмирання надземної частини рослини.

На наявність сапонінів досліджували водну і спиртово-водну витяжку листків і кореневищ 3 коренями первоцвіту весняного.

5 г подрібненої сировини поміщали в конічну колбу на 100 мл зі зворотним холодильником. Заливали 50 мл 50 \% етанолу P і нагрівали на водяній бані 15 хв. Після охолодження фрільтрували крізь складчастий фрільтр. 20 мл фрільтрату випаровували на водяній бані до 10 мл (звільняли від спирту). Одержану водну витяжку використовували для проведення проби на піноутворення і деяких осадових реакцій (з $10 \%$ розчином основного плюмбуму ацетату, 1 \% спиртовим розчином холестерину) $[8,9]$.
Також визначали хімічну природу сапонінів. В одну 3 двох мірних пробірок наливали 5 мл 0,1 Н кислоти хлоридної, в другу - 5 мл 0,1 Н розчину натрію гідроксиду. В обидві пробірки додавали по 3 краплі водної витяжки з листків та кореневищ з коренями первоцвіту весняного і збовтували протягом 1 хв [8].

Кількісне визначення сапонінів проводили таким методом: 2 г (точна наважка) сировини поміщали в патрон і екстрагували протягом 2 год (10 зливів) в апараті Сокслета хлороформом. Хлороформні витяжки відкидали. Потім проводили екстракцію 95 \% етанолом Р протягом 5 год (10 зливів). Розчинник відганяли на водяній бані до об'єму 1-2 мл, додавали 10 мл води очищеної Р і кількісно переносили в ділильну лійку, додавали 3 мл кислоти хлоридної та екстрагували сумішшю н-пропіловий спирт - хлороформ 2 рази по 70 мл. Отримані витяжки фрільтрували, і розчинник відганяли під вакуумом. Залишок у колбі розчиняли в кислоті ацетатній, переносили в колбу на 25 мл і доводили до мітки кислотою ацетатною (розчин А). 0,5 мл розчину А поміщали в колбу на 25 мл і доводили до мітки кислотою ацетатною (розчин Б). У пробірку наливали 2 мл розчину Б, 2 мл кобальту хлориду, 2 мл кислоти сульсратної і поміщали в киплячу водяну баню на 1 год. Потім пробірки швидко охолоджували. Оптичну густину розчину вимірювали на спектрофотометрі Lambda 25 UV при довжині хвиль 381 нм. Аналогічно готували розчин порівняння і стандартний розчин.

Приготування стандартного розчину і побудова калібрувального графріка. 0,0009, 0,0018, 0,0024 г есцину поміщали в колбу на 50 мл і доводили до мітки кислотою ацетатною. Потім готували аналогічно, як досліджуваний розчин і розчин порівняння.

Вміст сапонінів у перерахунку на есцин і абсолютно суху сировину у відсотках $(X)$ обчислювали за фрормулою:

$$
x=\frac{A \cdot 25 \cdot 25 \cdot 100}{m \cdot 0,5 \cdot(100-W)},
$$

де $A$ - оптична густина, знайдена за калібрувальним графріком;

25 - об'єм розчину А, мл;

25 - об'єм розчину Б, мл;

$m$ - маса сировини, г;

W - втрата в масі при висушуванні, \% [10]

РЕЗУЛЬТАТИ Й ОБГОВОРЕННЯ. ПОЯВа стійкої піни та позитивні реакції з $10 \%$ розчином основного плюмбуму ацетату й 1 \% спиртовим розчином холестерину свідчили про наявність сапонінів у кореневищах 3 коренями і листках досліджуваної рослини. 
При визначенні хімічної природи сапонінів результати досліджень показали, що листки та кореневища з коренями первоцвіту весняного містять сапоніни тритерпенового ряду.

Спектрофотометричне визначення кількісного вмісту сапонінів у досліджуваних об'єктах первоцвіту весняного представлено в таблиці.

Результати досліджень показали, що листки первоцвіту весняного містять $(1,27 \pm 0,02) \%$ сапонінів у перерахунку на есцин, кореневища 3 коренями - $(3,69 \pm 0,02) \%$.

Таблиця - Метрологічна характеристика результатів кількісного визначення вмісту сапонінів у листках і кореневищах з коренями первоцвіту весняного

\begin{tabular}{|c|c|c|c|c|c|c|c|c|c|}
\hline $\mathrm{m}$ & $f$ & $X_{i}$ & $X_{\text {cep }}$ & $\mathrm{S}^{2}$ & $\mathrm{~S}_{\text {cep }}$ & $\mathrm{P}$ & $\mathrm{t}(\mathrm{P}, f)$ & $\begin{array}{c}\text { Кількісний } \\
\text { вміст }\end{array}$ & $\varepsilon, \%$ \\
\hline \multicolumn{10}{|c|}{ Листки } \\
\hline \multirow[t]{5}{*}{5} & 4 & 1,267 & \multirow[t]{5}{*}{1,272} & \multirow[t]{5}{*}{0,00027} & \multirow[t]{5}{*}{0,007} & \multirow[t]{5}{*}{0,95} & \multirow[t]{5}{*}{2,78} & \multirow[t]{5}{*}{$1,27 \pm 0,02$} & \multirow[t]{5}{*}{1,597} \\
\hline & & 1,255 & & & & & & & \\
\hline & & 1,269 & & & & & & & \\
\hline & & 1,268 & & & & & & & \\
\hline & & 1,299 & & & & & & & \\
\hline \multicolumn{10}{|c|}{ Кореневища з коренями } \\
\hline \multirow[t]{5}{*}{5} & 4 & 3,666 & \multirow[t]{5}{*}{3,685} & \multirow[t]{5}{*}{0,00026} & \multirow[t]{5}{*}{0,007} & \multirow[t]{5}{*}{0,95} & \multirow[t]{5}{*}{2,78} & \multirow[t]{5}{*}{$3,69 \pm 0,02$} & \multirow[t]{5}{*}{0,544} \\
\hline & & 3,678 & & & & & & & \\
\hline & & 3,699 & & & & & & & \\
\hline & & 3,679 & & & & & & & \\
\hline & & 3,705 & & & & & & & \\
\hline
\end{tabular}

ВИСНОВКИ. 1. Експериментально доведено, що листки і кореневища з коренями первоцвіту весняного містять сапоніни тритерпенового ряду.

2. Уперше визначено кількісний вміст сапонінів у листках і підземних органах первоцвіту весняного, заготовлених на території Тернопільської області. Вміст сапонінів у листках становив 1,27 \%, у кореневищах з коренями - 3,69 \% у перерахунку на есцин.

\section{СПИСОК ЛІТЕРАТУРИ}

1. Попова Н. В. Лекарственные растения мировой фрлоры / Н. В. Попова, В. И. Литвиненко. А. С. Куцанян. - Х. : Діка плюс, 2016. - 318 с.

2. Довідник лікарських рослин [Електронний ресурс] / Первоцвіт весняний. - Режим доступу : http:// proherbs.org.ua/view/325/.

3. Broda B. Primula veris (L.) and Primula elatior (L.) Scherh. as medicinal plants / B. Broda // Acta Pol. Pharm. - 1952. - № 9 (1). - P. 55-76; 1952. - № 9 (2). P. 85-95.

4. Товстуха $€$. С. Золоті рецепти української народної медицини / Є. С. Товстуха. - К. : KM Publishing, 2010. - С. 292-293.

5. Особенности выделения сапонинов из корнеплодов растения Beta vulgaris L. / T. А. Брежнева, С. А. Атаманова, А. И. Сливкин [и др.] // Вестн. ВГУ. Серия "Химия. Биология. Фармация". -2004. - № 1. С. 152-155.

6. Белай І. М. Дослідження протиатеросклеротичного ефректу рослинних засобів, що містять сапоніни,

\section{REFERENCES}

1. Popova, N.V., Litvinenko, V.I., \& Kutsanyan, A.S (2016). Lekarstvennye rasteniya mirovoy flory [Medicinal plants of the world flora]. Kharkov: Dika plyus [in Russian]. в експерименті / І. М. Белай // Вісн. наук. дослідж. 1999. - № 2. - C. 45-47.

7. Дроздова И. Л. Тритерпеновые соединения травы икотника серого / И. Л. Дроздова, Т. И. Лупилина // Лекарственное растениеводство: от опыта прошлого к современным технологиям : материалы II Междунар. науч.-практ. интернет-конср. - Полтава, 2013. - С. 108-110.

8. Солодовниченко Н. М. Лікарська рослинна сировина та фрітопрепарати : посіб. з фрармакогнозії 3 основами біохімії лікарських рослин / Н. М. Солодовниченко, М. С. Журавльов, В. М. Ковальов. - Х. : Вид-во НФАУ : Золоті сторінки, 2001. - 408 с.

9. Практикум по фрармакогнозии : учеб. пособ. для студ. вузов / [В. Н. Ковалев, Н. В. Попова, В. С. Кисличенко и др.] ; под общ. ред. В. Н. Ковалева. - Х. : Изд-во НфаУ : Золотые страницы, 2003. - 512 с.

10. Фитохимический анализ лекарственного растительного сырья. - СПб. : Изд-во СПб. хим.-срарм. академии, 1998. - 59 с.

2. Dovidnyk likarskykh roslyn [Handbook of medicinal plants]. (n.d.). proherbs.org.ua. Retrieved from: http:// proherbs.org.ua/view/325/ [in Ukrainian]. 
3. Broda, B. (1952). Primula veris (L.) and Primula elatior (L.) Scherh. as medicinal plants. Acta Pol. Phar., 9 (1), 55-76; 9 (2), 85-95.

4. Tovstukha, Ye.S, (2010). Zoloti retsepty ukrainskoi narodnoi medytsyny [Golden Ukrainian recipes of folk medicine]. Kyiv: KM Publishing [in Ukrainian].

5. Brezhneva, T.A., Atamanova, S.A., Slivkin, A.I. (2004). Osobennosti vydeleniya saponinov iz korneplodov rasteniya Beta vulgaris L. [Features of saponins excretion from the roots crops of plant Beta vulgaris L.]. Vestnik VGU. Seriya: Khimiya. Biologiya. Farmatsiya - Journal of VSU. Series: Chemistry. Biology. Pharmacy, 1, 152-155 [in Russian].

6. Belai I.M. (1999). Doslidzhennia protyaterosklerotychnoho efektu roslynnykh zasobiv, shcho mistiat saponiny, v eksperymenti [Experimental investigation of antyaterosclerotic effect of herbal products containing saponins]. Vísnyk naukovykh doslidzhen - Journal of Scientific Researches, 2, 45-47 [in Ukrainian].

7. Drozdova, I.L. \& Lupilina, T.I. (2013). Triterpenovye soyedineniya travy ikotnika serogo [Triterpene compounds of gray hibiscus grass]. Proceedings of the second International Scientific and Practical Internet Conference "Lekarstvennoe rastenievodstvo: ot opyta proshlogo $k$ sovremennym tekhnologiyam" - "Medicinal plant growing: from past experience to modern technologies", (pp. 108110). Poltava [in Russian].

8. Solodovnychenko N.M., Zhuravlov M.S. \& Kovalov V.M. (2001). Likarska roslynna syrovyna ta fitopreparaty: posib. z farmakohnozii z osnovamy biokhimii likarskykh roslyn [Medicinal plants and herbal medicines, training manual. Pharmacognosy with basic biochemistry of medicinal plants]. Kharkiv: Vyd-vo NFAU: Zoloti storinky [in Ukrainian].

9. Kovalev, V.N., Popova, N.V., Kislichenko, V.S. (2003). Praktikum po farmakognozii: ucheb. posobiye dlya stud. vuzov [Workshop on Pharmacognosy]. V.N. Kovalev (Ed.). - Kharkov: Izd-vo NfaU: Zolotyye stranitsy [in Russian].

10. Fitokhimicheskiy analiz lekarstvennogo rastitelnogo syrya [Phytochemical analysis of medicinal plant material]. (1998). S-Pb: Izd- vo S-Pb khim.-farm. Akademii [in Russian].

С. М. Марчишин, Л. Г. Шостак, С. С. Наконечная, Т. Я. Ярошенко ТЕРНОПОЛЬСКИЙ ГОСУДАРСТВЕННЫЙ МЕДИЦИНСКИЙ УНИВЕРСИТЕТ ИМЕНИ И. Я. ГОРБАЧЕВСКОГО

\section{СОДЕРЖАНИЕ САПОНИНОВ В КОРНЕВИЩАХ С КОРНЯМИ И ЛИСТЬЯХ ПЕРВОЦВЕТА ВЕСЕННЕГО}

\section{Резюме}

Вступление. Первоцвет, или примула (Primula L.), - род растений семейства первоцветные (Primulaceae), который насчитывает около 500 видов, распространенных по всему земному шару. В странах СНГ растет 67 видов (по данным некоторых авторов - 80) рода, в Украине - 9; наиболее распространенным является первоцвет весенний. Первоцвет весенний (Primula veris L.) - лекарственное, витаминное, пищевое, медоносное, красильное, декоративное растение. Несмотря на широкое использование первоцвета весеннего в медицинской практике, химический состав его изучен недостаточно. В доступных источниках научной литературы отсутствуют данные об исследовании содержания сапонинов в листьях и подземных органах первоцвета весеннего фрлоры Украины.

Цель исследования - определить содержание сапонинов в листьях и корневищах с корнями первоцвета весеннего.

Методы исследования. На наличие сапонинов исследовали водную и спирто-водную вытяжку листьев и корневищ с корнями первоцвета весеннего. Водную вытяжку первоцвета весеннего использовали для проведения пробы на пенообразование и некоторых осадочных реакций. Также определяли химическую природу сапонинов. Количественное содержание сапонинов определяли спектрофотометрическим методом на спектрофотометре Lambda 25 UV при длине волн 381 нм. Пересчет вели на эсцин.

Результаты и обсуждение. Появление устойчивой пены и положительные реакции с 10 \% раствором основного свинца ацетата и 1 \% спиртовым раствором холестерина свидетельствовали о наличии сапонинов в корневищах с корнями и листьях исследуемого растения. При определении химической природы сапонинов установлено, что листья и корневища с корнями первоцвета весеннего содержат сапонины тритерпенового ряда. Результаты исследований показали, что листья первоцвета весеннего содержат $(1,27 \pm 0,02) \%$ сапонинов в пересчете на эсцин, корневища с корнями - $(3,69 \pm 0,02) \%$.

Выводы. Экспериментально доказано, что листья и корневища с корнями первоцвета весеннего содержат сапонины тритерпенового ряда. Впервые определено количественное содержание сапонинов в листьях и подземных органах первоцвета весеннего, заготовленных на территории Тернопольской области. Содержание сапонинов в листьях составило 1,27 \%, в корневищах с корнями - 3,69 \% в пересчете на эсцин.

КЛЮЧЕВЫЕ СЛОВА: первоцвет весенний; сапонины; листья; корневища с корнями. 


\section{CONTENT OF SAPONINS IN RHIZOMES WITH ROOTS AND LEAVES OF PRIMULA VERIS L.}

\section{Summary}

Introduction. Primrose or primula (Primula L.) is a genus of Primulaceae family plants, which includes about 500 species, distributed throughout the globe. 67 species (according to some authors - 80) grow in the CIS countries, in Ukraine - nine of them; the most common is Primula veris. Primula veris $L$. is a medicinal, vitamin, nutritional, honeyed, dyeing and decorative plant. Its chemical composition is insufficiently studied despite the widespread usage of primula in medical practice. There is no information about research of saponins contents in leaves and underground organs of Primula veris of Ukrainian flora in the available sources of scientific literature.

The aim of the study - to determine the content of saponins in leaves and rhizomes with roots of Primula veris.

Research Methods. Water and spirituous-water extracts of leaves and rhizomes with roots of Primula veris were studied for saponins content. The aqueous extract of primula was used for tests on foam formation and some sedimentary reactions. The determination of chemical nature of saponins was also done. Quantitative content of saponins was determined by spectrophotometric method on a spectrophotometer Lambda 25 UV at a wave length $381 \mathrm{~nm}$ with following conversion to aescin.

Results and Discussion. The emergence of stable foam and positive reactions with $10 \%$ solution of basic lead acetate and $1 \%$ alcoholic solution of cholesterol showed the presence of saponins in the leaves and rhizomes with roots of the studied plant. It was found out during determining the chemical nature of saponins that the leaves and rhizomes with roots of Primula veris contain triterpene saponins - $(1.27 \pm 0.02) \%$ and $(3.69 \pm 0.02) \%$ respectively in conversion to aescin.

Conclusion. It was experimentally proved that the leaves and rhizomes with roots of Primula veris contain triterpene saponins. For the first time it was defined quantitative content of saponins in leaves and underground organs of Primula veris from Ternopil region. The content of saponins in leaves was $1.27 \%$, in rhizomes with roots $3.69 \%$ in conversion to escin.

KEY WORDS: Primula veris; saponins; leaves; rhizomes with roots.

Адреса для листування: С. М. Марчишин, Тернопільський державний медичний університет імені І. Я. Горбачевського, майдан Волі, 1, Тернопіль, 46001, Україна, e-mail: marchyshyn@tdmu.edu.ua. 